Research Note-

\title{
Effects of Homologous and Heterologous Neuraminidase Vaccines in Chickens Against H5N1 Highly Pathogenic Avian Influenza
}

\author{
Y. J. Lee, ${ }^{\mathrm{A}}$ H. W. Sung, ${ }^{\mathrm{B}}$ J. G. Choi, ${ }^{\mathrm{A}}$ E. K. Lee, ${ }^{\mathrm{A}}$ O. M. Jeong, ${ }^{\mathrm{A}}$ Y. K. Kwon, ${ }^{\mathrm{A}}$ \\ J. H. Kwon, ${ }^{A}$ C. S. Song, ${ }^{C}$ and J. H. Kim ${ }^{A D}$

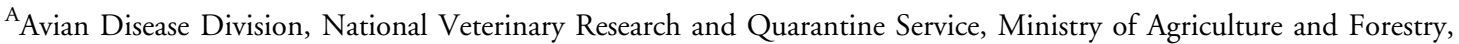 \\ 480 Anyang 6-dong, Anyang, Gyeonggi-do 430-016, Korea \\ ${ }^{B}$ Department of Veterinary Medicine, Kangwon National University, Chunchon 200-701, Korea \\ ${ }^{\mathrm{C}}$ Veterinary Science Research Institute, College of Veterinary Medicine, Konkuk University, \\ 1 Hwayang-dong, Kwangin-gu, Seoul 143-701, Korea
}

Received 31 March 2006; Accepted 15 August 2006

\begin{abstract}
SUMMARY. The 2004 Asian H5N1 epizootic outbreak indicates the urgent need for vaccines against highly pathogenic avian influenza (HPAI) virus. The manufacture of inactivated whole-virus vaccines from HPAI viruses by traditional methods is not feasible for safety reasons as well as technical issues. The low pathogenic avian influenza A/wild bird feces/CSM2/02 (H5N3) virus was used as a heterologous neuraminidase vaccine, and HPAI A/CK/Korea/ES/03 (H5N1) virus was used as a homologous neuraminidase vaccine. Protection efficacy of both vaccines was evaluated by clinical signs, mortality rates, and virus shedding from oropharynx and cloaca of vaccinated chickens after challenge with HPAI A/CK/Korea/ES/03 (H5N1) virus. One dose of 128 hemagglutinin (HA) homologous $\mathrm{H} 5 \mathrm{~N} 1$ vaccine induced $100 \%$ protection in mortality and prevented viral shedding completely after lethal dose virus challenge, whereas one dose of $64 \mathrm{HA}$ unit of heterologous $\mathrm{H} 5 \mathrm{~N} 3$ vaccine only induced $50 \%$ protection in mortality, and it did not prevent viral shedding. However, two doses at a 3-wk interval of $64 \mathrm{HA}$ unit of heterologous H5N3 vaccine as well as one dose of $1024 \mathrm{HA}$ unit of heterologous $\mathrm{H} 5 \mathrm{~N} 3$ vaccine induced $100 \%$ survival rate and could prevent viral shedding completely. Furthermore, we could differentiate the sera of infected birds from those of vaccinated birds by indirect immunofluorescent antibody test. These results suggest that heterologous neuraminidase H5N3 vaccine could be a useful tool for the control of H5N1 HPAI epidemic in poultry.
\end{abstract}

RESUMEN. Nota de Investigación-Efecto en pollos de vacunas homólogas y heterólogas de neuraminidasa contra el virus de influenza aviar $\mathrm{H} 5 \mathrm{~N} 1$ de alta patogenicidad.

La epizootia Asiática del año 2004 indica la necesidad urgente de vacunas contra influenza aviar de alta patogenicidad. La elaboración por los métodos tradicionales de vacunas inactivadas preparadas con virus completos a partir de virus de alta patogenicidad no es viable, tanto por razones de seguridad como por aspectos técnicos. El virus de influenza aviar de baja patogenicidad A/Wild bird feces/CSM2/02 (H5N3) se utilizó como una vacuna heteróloga de neuraminidasa y el virus de influenza aviar de alta patogenicidad A/CK/Korea/ES/03 (H5N1) se utilizó como una vacuna homóloga de neuraminidasa. Se evaluó la eficacia de la protección mediante la observación de signos clínicos, la tasa de mortalidad y la diseminación viral desde la orofaringe y cloaca de aves vacunadas posteriores a un desafio con el virus de influenza aviar de alta patogenicidad A/CK/Korea/ES/03 (H5N1). Una dosis de la vacuna homóloga H5N1 con un título de 128 unidades hemoaglutinantes indujo 100\% de protección en mortalidad y previno por completo la diseminación del virus luego de una dosis letal del virus de desafío, mientras una dosis con 64 unidades hemoaglutinantes de la vacuna heteróloga $\mathrm{H} 5 \mathrm{~N} 3$ solo indujo un $50 \%$ de protección en mortalidad y no previno la diseminación viral. Sin embargo, dos dosis con 64 unidades hemoaglutinantes de la vacuna heteróloga H5N3 con un intervalo de tres semanas, así como una dosis con 1024 unidades hemoaglutinantes de la vacuna heteróloga H5N3 indujeron una tasa de supervivencia del 100\% y pudieron prevenir por completo la diseminación viral. Así mismo, se pudo diferenciar el suero de las aves infectadas del de las aves vacunadas mediante la prueba de inmunofluorescencia indirecta para anticuerpos. Estos resultados sugieren que la vacuna heteróloga de neuraminidasa $\mathrm{H} 5 \mathrm{~N} 3$ puede ser una herramienta útil en el control de la epidemia de influenza aviar de alta patogenicidad $\mathrm{H} 5 \mathrm{~N} 1$ en las aves domésticas.

Key words: avian influenza, DIVA vaccine, H5N1, H5N3, highly pathogenic avian influenza

Abbreviations: $\mathrm{AI}=$ avian influenza; $\mathrm{ECE}=$ embryonated chicken egg; $\mathrm{EID}=$ embryo infectious dose; $\mathrm{HA}=$ hemagglutinin; $\mathrm{HI}=$ hemagglutination inhibition; HPAI = highly pathogenic avian influenza; $\mathrm{IFA}=$ indirect fluorescent antibody; $\mathrm{NA}=$ neuraminidase; $\mathrm{PCR}=$ polymerase chain reaction; $\mathrm{SPF}=$ specific pathogen free; $\mathrm{TCID}_{50}=0 \%$ tissue culture infective dose

During December 2003 and March 2004, South Korea had experienced an epidemic of highly pathogenic avian influenza (HPAI) caused by a type A influenza virus of the $\mathrm{H} 5 \mathrm{~N} 1$ subtype. In total, 19 domestic poultry farms (10 chicken farms and nine duck farms) were infected with the virus. Control measures included the depopulation of all poultry within a $3-\mathrm{km}$ radius protection zone (stamping out), quarantines, disinfection, movement restrictions, and surveillance. Approximately 5 million chickens and ducks were slaughtered and

${ }^{\mathrm{D}}$ Corresponding author. buried. At that time, the use of vaccines in such emergences was limited in South Korea. The main reason for vaccination bans was that vaccine-induced antibodies could interfere with serologic surveillance and epidemiological studies.

Influenza vaccination has been widely practiced to reduce the incidence of clinical disease in poultry, and in some cases it has been used as part of an avian influenza (AI) eradication strategy (8). Recently, the vaccination to HPAI in poultry has been increasing in China, Italy, Mexico, Pakistan, and other countries (1,2,4,6,7). Differentiation of infected from vaccinated animals strategies have been proposed to overcome impediment of AI vaccination 
Table 1. Protective effect and antibody response in chickens after vaccination with the virus possessing homologous neuraminidase N1 and heterologous neuraminidase N3 (trial 1).

\begin{tabular}{|c|c|c|c|c|c|c|}
\hline \multirow[b]{3}{*}{ Group } & \multirow[b]{3}{*}{ Vaccination } & \multirow{3}{*}{$\begin{array}{c}\text { HI titer } \\
(\log 2 \pm S D)^{B} \\
\end{array}$} & \multicolumn{4}{|c|}{ Results after challenge $(\%)^{\mathrm{A}}$} \\
\hline & & & \multicolumn{2}{|c|}{ Virus reisolation $^{\mathrm{C}}$} & \multirow[b]{2}{*}{ Clinical signs } & \multirow[b]{2}{*}{ Mortality } \\
\hline & & & Oropharynx & Cloaca & & \\
\hline H5N3-one & Once $^{F}$ & $2.7 \pm 1.9$ & $6 / 10(60)$ & $6 / 10(60)$ & $6 / 10(60)$ & $5 / 10(50)$ \\
\hline Control & Unvaccinated & 0.0 & $6 / 10(60)$ & $10 / 10(100)$ & $10 / 10(100)$ & $10 / 10(100)$ \\
\hline H5N1-two & Twice $^{\mathrm{G}}$ & $11.7 \pm 0.6$ & $0 / 8(0)$ & $0 / 8(0)$ & $0 / 8(0)$ & $0 / 8(0)$ \\
\hline
\end{tabular}

${ }^{\mathrm{A}}$ Challenge virus (A/CK/Korea/ES/03 (H5N1) with $10^{6.6} \mathrm{EID}_{50} /$ bird) was administered intranasally.

${ }^{\mathrm{B}} \mathrm{HI}$ titers $\log 2$ mean titer $\pm \mathrm{SD}$ after 3 wk after vaccination.

${ }^{\mathrm{C}}$ Samples were collected at 2, 3, 5, and 7 days postchallenge.

${ }^{\mathrm{D}}$ Once vaccination of 5-wk-old chickens with $128 \mathrm{HA}$ unit of A/CK/Korea/ES/03 (H5N1).

${ }^{\mathrm{E}} \mathrm{Number}$ virus reisolation over number in group.

${ }^{\mathrm{F}}$ Once vaccination of 5-wk-old chickens with $64 \mathrm{HA}$ unit of A/wild bird feces/Korea/CSM2/02 (H5N3).

${ }_{\text {G }}$ Twice vaccination at 5 and 8 wk with $128 \mathrm{HA}$ unit of A/CK/Korea/ES/03 (H5N1).

${ }^{\mathrm{H}}$ Twice vaccination at 5 and 8 wk with $64 \mathrm{HA}$ unit of A/wild bird feces/Korea/CSM2/02 (H5N3).

$(1,3,9,10)$. Recently, there is a possibility of the risk of re-entry H5N1 HPAI to South Korea because of the recent Asian H5N1 epizootic outbreak. Because the use of highly pathogenic $\mathrm{H} 5 \mathrm{~N} 1$ strains has safety restrictions, the $\mathrm{H} 5 \mathrm{~N} 3$ virus with heterologous neuraminidase (NA) capable of evoking cross-reactive immunity to the $\mathrm{H} 5 \mathrm{~N} 1 \mathrm{HPAI}$ virus was investigated. Vaccination seems to remain the principal means of combating pandemic influenza.

\section{MATERIALS AND METHODS}

Viruses and vaccines. The $\mathrm{A} / \mathrm{CK} / \mathrm{Korea} / \mathrm{ES} / 03[\mathrm{H} 5 \mathrm{~N} 1](\mathrm{CK} / \mathrm{Kr} /$ $\mathrm{ES} / 03$ ) strain was isolated from chickens from the first infected case of HPAI in South Korea in 2003, and the other A/wild bird feces/Korea/ CSM2/02 [H5N3] (Wbf/Kr/CSM2/02) strain was isolated from wild bird feces during active surveillance of migratory birds in 2002. Viruses were propagated in 10-day-old specific pathogen free (SPF) embryonated chicken eggs (ECEs). Each virus was inactivated and was used for vaccine preparation with oil adjuvant (ISA70; Seppic, Paris, France). For experiments, chickens were vaccinated intramuscularly with $0.5 \mathrm{ml}$ of inactivated oil emulsion vaccine. All experiments with live viruses were performed in a biosafety level 3 containment facility at National Veterinary Research and Quarantine Service in South Korea.

Sequence analysis. Viral RNAs were extracted using RNeasy mini kit (QIAGEN, Valencia, CA) from infectious allantoic fluid from ECEs. Standard reverse transcription-polymerase chain reaction (PCR) was performed using One-Step RT-PCR kit (QIAGEN) with primers specific for influenza virus as described Lee et al. (5). The sequences of CK/Kr/ES/ 03 were deposited in the GenBank (see accession number in reference 5).

Chickens. In trial 1, 30 5-wk-old SPF chickens were divided into three groups for protective efficacy test after one-dose vaccination of each vaccine. Ten chickens were vaccinated one time with $\mathrm{CK} / \mathrm{Kr} / \mathrm{ES} / 03$
(H5N1) vaccine (H5N1-one). The other 10 chickens were vaccinated one time with wbf/Kr/CMS2/02 (H5N3) vaccine (H5N3-one). The remaining 10 chickens served as unvaccinated controls.

In addition, 245 -wk-old SPF chickens were divided into three groups for efficacy test with two doses injected at a 3-wk interval of each vaccine. The chickens for the $\mathrm{H} 5 \mathrm{~N} 1$ two-dose vaccination group (H5N1-two) and $\mathrm{H} 5 \mathrm{~N} 3$ two-dose vaccination group $(\mathrm{H} 5 \mathrm{~N} 3$-two) were vaccinated with $\mathrm{H} 5 \mathrm{~N} 1$ and $\mathrm{H} 5 \mathrm{~N} 3$ vaccine, respectively. The chickens of each group were vaccinated a second time $3 \mathrm{wk}$ after the first vaccination. The remaining eight chickens served as unvaccinated controls.

For protective efficacy test against $\mathrm{H} 5 \mathrm{~N} 1 \mathrm{HPAI}$, chickens of each group were challenged through intranasal route with $10^{6.6} 50 \%$ embryo infectious dose $\left(\mathrm{EID}_{50}\right) / 0.1 \mathrm{ml} \mathrm{CK} / \mathrm{Kr} / \mathrm{ES} / 03(\mathrm{H} 5 \mathrm{~N} 1)$ virus at $3 \mathrm{wk}$ after once or twice vaccination. Clinical signs and mortality rates were observed for 2 wk after lethal virus challenge. Swab samples were collected at 2, 3, 5, and 7 days postchallenge from oropharynx and cloacae for virus isolation in chicken embryo fibroblast cells.

In trial 2, the isolate $\mathrm{Wbf} / \mathrm{Kr} / \mathrm{CSM} 2 / 02(\mathrm{H} 5 \mathrm{~N} 3)$ was concentrated to 10 times (1024 HA unit) by centrifuging at $18,000 \mathrm{rpm}$ for $3 \mathrm{hr}$. Manipulation of inactivated vaccine containing the 1024 hemagglutinin (HA) unit of virus and vaccination was done as described above to 10 12-wk-old chickens.

Serological analysis. Sera from vaccinated and challenged birds were tested for detection of antibodies to the $\mathrm{H} 5$ by hemagglutination inhibition (HI) test. For HI test, titers were determined using serial twofold diluted sera with both of $\mathrm{H} 5 \mathrm{~N} 1$ and $\mathrm{H} 5 \mathrm{~N} 3$ antigens. NA subtype-specific antibodies were detected with indirect immunofluorescent antibody (IFA) assay. For IFA assay, the N1 protein of CK/ $\mathrm{Kr} / \mathrm{ES} / 03$ (H5N1) was expressed using the BacPAK Baculovirus expression system (Clontech, Mountain View, CA) according to the manufacturer's instructions. Antigen for the IFA was prepared as follows in that Spodoptera frugiperda (Sf21) cells were infected with recombinant

Table 2. Protective effect and antibody response after vaccination with high quantity of antigen possessing heterologous neuraminidase N3 (trial 2).

\begin{tabular}{|c|c|c|c|c|c|}
\hline \multirow[b]{3}{*}{ Group } & \multirow{3}{*}{$\begin{array}{c}\text { HI titer } \\
(\log 2 \pm S D)^{\mathrm{B}}\end{array}$} & \multicolumn{4}{|c|}{ Results after challenge $(\%)^{\mathrm{A}}$} \\
\hline & & \multicolumn{2}{|c|}{ Virus reisolation $^{\mathrm{C}}$} & \multirow[b]{2}{*}{ Clinical signs } & \multirow[b]{2}{*}{ Mortality } \\
\hline & & Oropharynx & Cloaca & & \\
\hline Control & 0.0 & $10 / 10(100)$ & $10 / 10(100)$ & $10 / 10(100)$ & $10 / 10(100)$ \\
\hline
\end{tabular}

${ }^{\mathrm{A}}$ Challenge virus $\left[\mathrm{A} / \mathrm{CK} / \mathrm{Korea} / \mathrm{ES} / 03(\mathrm{H} 5 \mathrm{~N} 1)\right.$ with $\left.10^{6.6} \mathrm{EID}_{50} / \mathrm{bird}\right]$ was administered intranasally.

${ }^{\mathrm{B}} \mathrm{HI}$ titers $\log 2$ mean titer $\pm \mathrm{SD}$ after 3 wk after vaccination.

${ }^{\mathrm{C}}$ Samples were collected at 2, 3, 5, and 7 days postchallenge.

DVaccination of 12-wk-old chickens with $1024 \mathrm{HA}$ unit of A/wild bird feces/Korea/CSM2/02 (H5N3).

${ }^{\mathrm{E}} \mathrm{Number}$ virus reisolation over number in group. 
baculovirus at a multiplicity of infection of 5 . After $48 \mathrm{hr}$ of inoculation at $28 \mathrm{C}$, cells were harvested and reacted with sera from vaccinated and infected birds. Cells were observed for fluorescence after adding a fluorescein isothiocyanate-conjugated anti-chicken IgG.

\section{RESULTS AND DISCUSSION}

Protection studies. The nucleotide homology of HA between HPAI $\mathrm{CK} / \mathrm{Kr} / \mathrm{ES} / 03$ challenge strain and low pathogenic avian influenza $\mathrm{Wbf} / \mathrm{Kr} / \mathrm{CSM} 2 / 02$ vaccine strain was $91.1 \%$, whereas the homology of NA gene between them was $54.6 \%$. The amino acid similarity of HA proteins between these viruses was $92.9 \%$. The amino acid sequences of cleavage site of HA protein were RERKKR/GLFGA in $\mathrm{CK} / \mathrm{Kr} / \mathrm{ES} / 03$ and RETR/GLFGA in Wbf/Kr/CSM2/02 (H5N3).

In trial 1 , the one dose of heterologous $\mathrm{H} 5 \mathrm{~N} 3$ vaccine group (H5N3-one) showed relatively low protective efficacy compared with the one dose of homologous $\mathrm{H} 5 \mathrm{~N} 1$ vaccine group (H5N1-one) after challenge with $\mathrm{H} 5 \mathrm{~N} 1 \mathrm{HPAI}$ virus (Table 1). Mortality rate of $\mathrm{H} 5 \mathrm{~N} 3$ one group was $50 \%$, whereas that of $\mathrm{H} 5 \mathrm{~N} 1$-one group was $0 \%$. Neither $\mathrm{H} 5 \mathrm{~N} 3$-one nor $\mathrm{H} 5 \mathrm{~N} 1$-one group showed complete protective effect in virus shedding $\left(10^{1}-10^{3} 50 \%\right.$ tissue culture infective dose $\left[\mathrm{TCID}_{50}\right] / 0.1 \mathrm{ml}$ and $10^{1} \mathrm{TCID}_{50} / 0.1 \mathrm{ml}$, respectively). Unvaccinated control chickens showed $100 \%$ mortality and exhibited $60 \%$ and $100 \%$ virus shedding in oropharynx and cloaca, respectively $\left(10^{2}-10^{5} \mathrm{TICD}_{50} / 0.1 \mathrm{ml}\right)$. Although homologous $\mathrm{H} 5 \mathrm{~N} 1$ vaccine induced more effective disease prevention results than that of heterologous $\mathrm{H} 5 \mathrm{~N} 3$ vaccine, the use of highly pathogenic strains has safety restriction, especially in the commercial vaccine plant. Furthermore, $\mathrm{H} 5 \mathrm{~N} 1$ vaccine-induced antibodies were incapable of differentiating from antibodies taken from chickens infected with the field strain. Therefore, we investigated the possibility of a two-dose 3-wk interval vaccination scheme to improve the protective efficacy of heterologous $\mathrm{H} 5 \mathrm{~N} 3$ vaccine. The two doses of heterologous $\mathrm{H} 5 \mathrm{~N} 3$ vaccine as well as one dose of homologous $\mathrm{H} 5 \mathrm{~N} 1$ vaccine induced complete protective effect in mortality and reduced virus shedding completely against $\mathrm{H} 5 \mathrm{~N} 1 \mathrm{HPAI}$ virus challenge.

Finally, we tried to improve the efficacy of heterologous $\mathrm{H} 5 \mathrm{~N} 3$ vaccine with a one-dose vaccination scheme in trial 2 . To increase antigen quantity, viral antigen was concentrated to 10 times by centrifugation. Chickens vaccinated with heterologous $\mathrm{H} 5 \mathrm{~N} 3$ vaccine containing high antigen quantity (1024 HA unit) showed $100 \%$ protection in mortality, and virus shedding was reduced completely after $\mathrm{H} 5 \mathrm{~N} 1 \mathrm{HPAI}$ virus challenge after one dose of vaccination (Table 2 ). These results showed that one dose of $1024 \mathrm{HA}$ unit heterologous $\mathrm{H} 5 \mathrm{~N} 3$ vaccine is a candidate vaccine for the preventing $\mathrm{H} 5 \mathrm{~N} 1 \mathrm{HPAI}$.

Previous studies demonstrated that inactivated vaccines containing the same HA subtype as the challenge virus protected the birds from challenge regardless of the NA subtype $(1,9)$. Moreover, they reported that there was no positive correlation between the sequence identity of the HA gene with range $96.8 \%-100 \%$ and the ability to reduce the quantity of challenge virus shed, but there was a correlation between the antigen quantity and all parameters of protection (9). We obtained similar results in that although there was low sequence identity between the vaccinated and challenged strain, the vaccinated strain could protect birds challenged with HPAI virus. Therefore, antigen quantity in the same HA subtype would be a more important factor for protective efficacy of the vaccine.

Serological studies. The HI titers and IFA reactivity to recombinant N1 antigen are presented in Table 3. The HI titers of chickens vaccinated with $\mathrm{H} 5 \mathrm{~N} 1$ were higher than those of the vaccinated group with $\mathrm{H} 5 \mathrm{~N} 3$ after vaccination (trial 1). Seroconversion after challenge was evident in the group $\mathrm{H} 5 \mathrm{~N} 1$ challenge after $\mathrm{H} 5 \mathrm{~N} 3$ vaccination (v-H5N3, c-H5N1) compared with those of group $\mathrm{H} 5 \mathrm{~N} 1$
Table 3. Serological test in chickens after vaccination and challenge with homologous antigen, heterologous antigen, and recombinant N1 antigen.

\begin{tabular}{|c|c|c|c|c|}
\hline \multirow[b]{2}{*}{ Group } & \multirow[b]{2}{*}{$\begin{array}{c}\text { No. of } \\
\text { serum tested }\end{array}$} & \multicolumn{2}{|c|}{ HI titer $(\log 2 \pm S D)$} & \multirow{2}{*}{$\begin{array}{l}\text { IFA reaction } \\
\text { with recombinant } \\
\mathrm{N} 1 \text { antigen }\end{array}$} \\
\hline & & $\begin{array}{l}\text { H5N1 } \\
\text { Antigen }\end{array}$ & $\begin{array}{l}\mathrm{H} 5 \mathrm{~N} 3 \\
\text { Antigen }\end{array}$ & \\
\hline $\mathrm{v}-\mathrm{H} 5 \mathrm{~N} 1^{\mathrm{A}}$ & 10 & $8.6 \pm 1.8$ & $6.1 \pm 1.3$ & $8 / 10^{\mathrm{B}}$ \\
\hline $\begin{array}{l}\mathrm{v}-\mathrm{H} 5 \mathrm{~N} 3^{\mathrm{C}} \\
\mathrm{v}-\mathrm{H} 5 \mathrm{~N} 1\end{array}$ & 10 & $2.7 \pm 1.9$ & $4.3 \pm 2.3$ & $0 / 10$ \\
\hline $\begin{array}{l}\mathrm{c}-\mathrm{H} 5 \mathrm{~N} 1{ }^{\mathrm{D}} \\
\mathrm{v}-\mathrm{H} 5 \mathrm{~N} 3\end{array}$ & 10 & $9.2 \pm 0.8$ & $7.1 \pm 0.9$ & $10 / 10$ \\
\hline $\mathrm{c}-\mathrm{H} 5 \mathrm{~N} 1^{\mathrm{E}}$ & 5 & $7.4 \pm 1.1$ & $8.8 \pm 1.3$ & $5 / 5$ \\
\hline Control & 10 & 0.0 & 0.0 & $0 / 10$ \\
\hline
\end{tabular}

${ }^{\mathrm{A}}$ Chickens after 3-wk vaccination with $\mathrm{CK} / \mathrm{Kr} / \mathrm{ES} / 03$ (H5N1).

${ }^{\mathrm{B}}$ Number of positive reactivity over number in group.

${ }^{\mathrm{C}}$ Chickens after 3-wk vaccination with $\mathrm{Wbf} / \mathrm{Kr} / \mathrm{CSM} 2 / 02$ (H5N3).

${ }^{\mathrm{D}}$ Chickens challenged with $\mathrm{CK} / \mathrm{Kr} / \mathrm{ES} / 03$ (H5N1) after vaccination with $\mathrm{H} 5 \mathrm{~N} 1$.

${ }^{\mathrm{E}}$ Chickens challenged with $\mathrm{CK} / \mathrm{Kr} / \mathrm{ES} / 03(\mathrm{H} 5 \mathrm{~N} 1)$ after vaccination with $\mathrm{H} 5 \mathrm{~N} 3$.

challenge after $\mathrm{H} 5 \mathrm{~N} 1$ vaccination (v-H5N1, c-H5N1). The HI titers were higher using homologous viral $\mathrm{HI}$ antigen than heterologous viral $\mathrm{HI}$ antigen. Chickens exhibited positive results in both the vaccinated and challenged group with $\mathrm{H} 5 \mathrm{~N} 1$ by using IFA assay to recombinant $\mathrm{N} 1$ antigen. Thus, IFA assay with recombinant $\mathrm{N} 1$ would detect $\mathrm{H} 5 \mathrm{~N} 1$-infected chickens without clinical signs after $\mathrm{H} 5 \mathrm{~N} 3$ vaccination. Accordingly, heterologous $\mathrm{H} 5 \mathrm{~N} 3$ vaccine would be a useful tool for controlling epidemic HPAI in poultry caused by $\mathrm{H} 5 \mathrm{~N} 1$ virus.

\section{REFERENCES}

1. Capua, I., C. Terregino, G. Cattoli, F. Mutinelli, and J. F. Rodriguez. Development of a DIVA (differentiating infected from vaccinated animals) strategy using a vaccine containing a heterologous neuraminidase for the control of avian influenza. Avian Pathol. 32:47-55. 2002.

2. Garcia, A., H. Johnson, D. Kumar Srivastava, D. A. Jayawardence, D. R. Wehr, and R. G. Webster. Efficacy of inactivated H5N2 influenza vaccines against lethal A/chicken/Queretaro/19/95 infection. Avian Dis. 42: 248-256. 1998.

3. Lee, C. W., and D. L. Suarez. Avian influenza virus: prospects for prevention and control by vaccination. Anim. Health Res. Rev. 6:1-15. 2005.

4. Lee, C. W., D. A. Senne, and D. L. Suarez. Effect of vaccine use in the evolution of Mexican lineage H5N2 avian influenza virus. J. Virol. 78: 8372-8381. 2004.

5. Lee, C. W., D. L. Suarez, T. M. Tumpey, H. W. Sung, Y. K. Kwon, Y. J. Lee, J. G. Choi, S. J. Joh, M. C. Kim, E. K. Lee, J. M. Park, X. Lu, J. M. Katz, E. Spackman, D. E. Swayne, and J. H. Kim. Characterization of highly pathogenic $\mathrm{H} 5 \mathrm{~N} 1$ avian influenza A viruses isolated from South Korea. J. Virol. 79:3692-3702. 2005.

6. Li, C., G. Tian, Y. Li, D. Yu, K. Yu, and H. Chen. Antigenic and genetic analysis of the $\mathrm{H} 9 \mathrm{~N} 2$ avian influenza viruses isolated in China. Int. Congr. Ser. 1263:762-765. 2004.

7. Naeem, K. The avian influenza H7N3 outbreak in South Central Asia. In: Proc. Fourth International Symposium on Avian Influenza, Athens, GA. p. 31-35. 1998.

8. Suarez, D. Overview of avian influenza DIVA test strategies. Biologicals 33:221-226. 2005.

9. Swayne, D. E., J. R. Beck, M. Garcia, and H. D. Stone. Influence of virus strain and antigen mass on efficacy of $\mathrm{H} 5$ avian influenza inactivated vaccines. Avian Pathol. 28:245-255. 1999.

10. Tumpey, T. M., R. Alvarez, D. E. Swayne, and D. L. Suarez. Diagnostic approach for differentiating infected from vaccinated poultry on the basis of antibodies to NS1, the nonstructural protein of influenza A virus. J. Clin. Microbiol. 43:676-683. 2005. 